\title{
Survey on attitudes of Italian pediatricians toward cough
}

\author{
Alessandro Zanasi' \\ Luigi Morcaldi² \\ Salvatore Cazzato ${ }^{3}$ \\ Massimiliano Mazzolini ${ }^{4}$ \\ Marzia Lecchi ${ }^{5}$ \\ Antonio Maria Morselli- \\ Labate $^{6}$ \\ Marianna Mastroroberto ${ }^{6}$ \\ Roberto W Dal Negro ${ }^{7}$ \\ 'Italian Association for Cough Study, \\ Bologna, ${ }^{2}$ National Observatory \\ of Health in Childhood and \\ Adolescence (PAIDOSS: Osservatorio \\ Nazionale sulla Salute dell'Infanzia e \\ dell'Adolescenza), Rome, ${ }^{3}$ Department \\ of Pediatrics, Salesi Children's \\ Hospital, Ancona, ${ }^{4}$ Department \\ of Specialist, Diagnostic and \\ Experimental Medicine, Respiratory \\ and Critical Care Unit, S.Orsola- \\ Malpighi Hospital, University of \\ Bologna, Bologna, ${ }^{5}$ Department of \\ Biotechnology and Biosciences, \\ University of Milan Bicocca, \\ Milan, ${ }^{6}$ Department of Medical \\ and Surgical Sciences, Alma Mater \\ Studiorum, University of Bologna, \\ Bologna, ${ }^{7}$ National Centre for \\ Respiratory Pharmacoeconomics and \\ Pharmacoepidemiology, Verona, Italy
}

Correspondence: Roberto W Dal Negro National Centre for Respiratory

Pharmacoeconomics and Pharmacoepidemiology, Via Gabriele Rossetti, 4, 37I 24 Verona, Italy Tel +393483168888

Email robertodalnegro@gmail.com
This article was published in the following Dove Press journal:

ClinicoEconomics and Outcomes Research

16 March 2017

Number of times this article has been viewed

Context: Children's cough is a daily concern for most pediatricians. The management of both acute and chronic cough requires a systematic and comprehensive approach. Despite the approved protocols for management, the pediatric assessment of cough and the corresponding prescribing attitude frequently do not fit these protocols, which can be affected by parental suggestions - sometimes substantially.

Objective: The objective of this study was to investigate both the perception and the behavior of a representative sample of Italian pediatricians toward cough in real life.

Methods: A specific questionnaire consisting of 18 questions was prepared. The questionnaire was completed by 300 pediatricians (all members of PAIDOSS: Italian National Observatory on Health of Childhood and Adolescence) who represented 300,000 children.

Results: A vast majority of children have cough throughout the year ( $99.3 \%$ of respondents have cough during autumn/winter and $64.7 \%$ in spring/summer). Allergic disease is the most frequent suspected cause of chronic cough in children (53\%), and this is supported by the high demand for consultations: $73 \%$ seek the opinion of allergologists, $62 \%$ of otorhinolaryngologists and only $33 \%$ of pulmonologists. The majority of pediatricians $(92 \%)$ reported that they prescribe therapy in acute cough regardless of cough guidelines. Moreover, the survey pointed out the abuse of aerosol therapy (26\% in acute cough and 38\% in chronic cough) and of antibiotics prescription ( $22 \%$ in acute cough and $42 \%$ in chronic cough).

Conclusion: Our survey suggests that some Italian pediatricians' therapeutic attitudes should be substantially improved in order to achieve better management of cough in children and to minimize the burden of cough.

Keywords: acute cough, chronic cough, cough in children, pediatricians' prescriptions, cough impact

\section{Introduction}

Children's cough is a daily concern for most of pediatricians. In the majority of cases, cough is self-limiting, but its persistence could become annoying and could impair both quality of life and social activities. ${ }^{1}$ The management of both acute and chronic cough requires a systematic and comprehensive approach. Nevertheless, according to the American Food and Drug Administration, inappropriate prescription and use of antitussive drugs in children are being reduced when compared to those of other pharmaceutical classes. ${ }^{2}$ In the last few years, several protocols oriented to the improved identification of the causes of cough and to cough resolution were validated. ${ }^{3}$ Despite the significant benefits from their application, prescribing attitudes do not always reflect the presence of a correct diagnostic evaluation of cough. Several studies have described 
the prescription attitudes in children suffering from respiratory problems in the USA and Europe. ${ }^{4-6}$ The results showed a wide disagreement between guidelines' recommendations and present prescriptions. In the USA, the most prescribed drugs to children aged up to 11 years were old antibiotics (amoxicillin and azithromycin), with cough, asthma, and allergy being the most frequent respiratory conditions for which patients received prescriptions. ${ }^{6}$ Frequent mistakes were also observed in dosing and in the route of administration of drugs. ${ }^{2}$ The use of antibiotics for acute cough is still high across the world ${ }^{7-9}$ and represents a primary concern about the development of antibiotic resistance. ${ }^{10,11}$ However, treatment represents only part of the economic burden due to cough. ${ }^{12,13}$ The identification of the cause of cough is crucial in order to determine the right treatment. Although several tests can be done for investigating chronic cough and defining the correct approach to speed up diagnosis and treatment, misuse of some tests (i.e., spirometry, chest radiography, head-neck computed tomography, allergic tests) may increase costs and delay both the diagnosis and the approach to the appropriate therapy. ${ }^{1,14,15}$ Moreover, pediatric evaluations can be compromised by parental perceptions: parents often exaggerate symptoms and/or require prescription of specific drugs, such as antibiotics, commonly regarded as the only effective therapeutic option. ${ }^{16,17}$

Therefore, we conducted a survey on a representative sample of Italian pediatricians in order to investigate their approach and prescription attitudes toward acute and chronic cough.

\section{Methods}

The survey was planned and carried out by Italian Association for Cough Study (AIST) and National Centre for Respiratory Pharmacoeconomics and Pharmacoepidemiology, in cooperation with the Italian National Observatory on Health of Childhood and Adolescence (PAIDOSS, which is a scientific society of pediatricians with the mission to promote childhood and adolescence health). The AIST Ethical Committee approved the study on October 15, 2014.

A specific questionnaire was designed in order to investigate both the perceptions and the behaviors of pediatricians toward cough in their young patients (Supplementary material). It consisted of 18 questions that were either multiple choice or open ended. The first eight questions were aimed to investigate the prevalence and the type of cough and to collect some information on pediatricians' medical activity. The second part of the questionnaire included the last ten questions that were aimed to investigate the pediatricians' approach to cough, such as their etiological definition, diagnostic attitude, and prescription habits. A cover letter providing background information and the aim of the study preceded the request to participating in the survey.

The questionnaire was directly distributed to all the PAIDOSS members (300 pediatricians from 15 Italian regions) at the registration of the PAIDOSS National Meeting, Capri, Italy, 2014, and collected at the end of the meeting, when they asked for their certificate of attendance.

As four questions about cough causes were open ended, we first pooled causes and treatments in order to avoid duplicate items during analysis. In order to check possible regional differences in the cultural approach to cough, Italian regions were divided into three geographical areas: Northern (Emilia Romagna, Friuli Venezia Giulia, Lombardia, Piemonte, Veneto), Central (Lazio, Marche, Sardegna, Toscana, Umbria), and Southern (Abruzzo, Calabria, Campania, Puglia, Sicilia). All questionnaires were anonymous. The return of the questionnaire was considered as evidence of informed consent.

\section{Statistics}

Means, standard deviation, minimum, maximum, and interquartile range (IQR) were used in order to describe scalar data, while absolute and relative frequencies were used in order to describe discrete data. Scalar data were analyzed by using the Kruskal-Wallis test. As far as discrete data were concerned, the Pearson's chi-square test was applied in order to test the overall relationship between variables, while the hierarchical log-linear model was used to compare the observed versus the expected value of each single frequency. The type of cough (dry or productive) was compared between acute and chronic cough by means of the McNemar test since paired data were involved. Data were managed and analyzed by means of the IBM SPSS Statistics (version 23; IBM, Co., Armonk, NY, USA) package, and two-tailed $p$ values $<0.05$ were considered statistically significant.

\section{Results}

Approximately one-half of respondents $(48.0 \% ; n=144)$ were located in Southern Italy, while $22.0 \%(n=66)$ were from the Central region and $30.0 \%(n=90)$ from the Northern region. Their average seniority in the public health care service was 21.6 \pm 8.5 years (IQR: $18-28$ years; range: $1-40$ years). The potential overall number of children referring to the 300 pediatricians surveyed was $>282,000$ (range of age 3-14 years), with a mean of $954 \pm 170$ patients/pediatrician (IQR: $850-1,000$ patients; range: 600-1,900 patients). 
Seniority and number of assisted children were significantly different among the three Italian areas ( $p=0.027$ and $p<0.001$, respectively). Even if no correlation was found between seniority and the survey responses, in Northern regions, there was a lower seniority $(18.8 \pm 10.8$ years vs $22.8 \pm 8.1$ years and 22.9 \pm 6.5 years in Central and Southern regions, respectively) and a significantly greater number of assisted children $(1,031 \pm 167$ vs $938 \pm 207$ and $912 \pm 136$ in Central and Southern regions, respectively).

\section{Impact of cough}

The vast majority of pediatricians $(n=298 ; 99.3 \%$ of respondents) reported that in winter, cough represents a true huge problem, frequently leading patients to seek for a visit. However, 194 pediatricians $(64.7 \%)$ registered a high prevalence of visits for cough also in summer and spring. Most of the pediatricians $(n=247 ; 82.3 \%)$ made more than one visit for cough to the same patient during the year. The frequency of visits to the same patient was not significantly different among the three Italian areas $(p=0.095, p=0.087$, and $p=0.126$, respectively), independent of seasons.

Acute cough was described as more frequently dry than productive $(n=217,72.3 \%$, vs $n=83,27.7 \%)$, while chronic cough was more frequently productive than dry $(n=176$, $58.7 \%$, vs $n=124,41.3 \%$ ). This difference observed between acute and chronic cough proved significantly different $(p<0.001)$.

\section{Investigations}

Specific investigations were not frequently requested in patients with acute cough; actually, they were usually requested by only 43 pediatricians $(14.3 \%)$. The most common tests were chest radiography $(n=26,60.5 \%$ of the total number of tests) and allergologic tests $(n=35,81.4 \%)$, but only eight physicians (18.6\%) required spirometry.

In children with chronic cough, $73.5 \%$ of pediatricians ( $n=219$ out of 298 available responses) usually prescribed additional tests, and the most common investigations were allergologic tests $(n=183,83.6 \%)$, chest radiography $(\mathrm{n}=127,58.0 \%)$, sweat test $(\mathrm{n}=103,47.0 \%)$, spirometry $(\mathrm{n}=73,33.3 \%), \mathrm{pH}$-metry test $(\mathrm{n}=24,11.0 \%)$, and head-neck computed tomography $(n=10,4.7 \%)$. Moreover, out of 293 available responses, allergologists and otorhinolaryngologists were the most common specialists to whom patients were addressed for a consultation $(n=213,72.7 \%$, and $\mathrm{n}=182,62.1 \%$, respectively). Pneumologists and gastroenterologists were consulted only by $33.1 \%(n=97)$ and $17.7 \%$ $(n=52)$ of the cases, respectively. However, there were some geographical differences in requests for consultations of otorhinolaryngologists $(p=0.030)$, pneumologists $(p=0.001)$, and gastroenterologists $(p=0.006$; Table 1). In particular, pneumologists were significantly less frequently consulted in the Southern area $(p<0.001 ; 22.2 \%$ vs $43.7 \%$ and $43.5 \%$ in Southern vs Northern and Central Italy, respectively), whereas gastroenterologists were significantly more frequently consulted in the Southern compared to the Northern and the Central regions ( $p=0.002 ; 25.0 \%$ vs $11.5 \%$ and $9.7 \%$ in Southern vs Northern and Central regions, respectively). A significantly lower frequency of otorhinolaryngologist consultations was also found in Northern Italy $(50.6 \% ; p=0.012)$ in comparison to that in Central and Southern Italy $(66.1 \%$ and $67.4 \%$, respectively).

\section{Causes of cough}

The most presumed causes of acute cough were infectious diseases, particularly airway viral infections $(n=134,44.7 \%)$, upper respiratory tract infections (URTIs; $n=92,30.7 \%$ ), and lower respiratory tract infections (LRTIs; $n=22,7.3 \%$; Table 2). In particular, viral infections were more frequently indicated as the main cause of acute cough in the Southern areas $(72 / 144,50.0 \% ; p=0.012)$ and less frequently in Central regions $(22 / 66,33.3 \% ; p=0.016)$. URTIs were more frequently diagnosed in Southern $(49 / 144,34.0 \% ; p=0.034)$ than in Northern regions $(19 / 90,21.1 \% ; p=0.048)$, while the frequency of LRTIs as the main cause of acute cough did not show any significant difference across Italian areas. Allergic disorders (including asthma and rhinitis) were suggested in $14.7 \%$ of cases of acute cough $(n=44)$ and were significantly

Table I Geographical distribution of requests for consultations in patients with chronic cough

\begin{tabular}{|c|c|c|c|c|c|}
\hline \multirow[t]{2}{*}{ Specialist consulted } & \multirow{2}{*}{$\begin{array}{l}\text { Overall Italy } \\
(n=293)\end{array}$} & \multicolumn{3}{|l|}{ Italian areas } & \multirow{2}{*}{$\begin{array}{l}\text { Overall } \\
\text { p-value }^{a}\end{array}$} \\
\hline & & Northern $(n=87)$ & Central $(n=62)$ & Southern $(n=144)$ & \\
\hline Allergologists & $213(72.7 \%)$ & 65 (74.7\%), $p=0.598$ & 44 (7I.0\%), $p=0.680$ & 104 (72.2\%), $p=0.923$ & 0.866 \\
\hline Otorhinolaryngologists & $182(62.1 \%)$ & $44(50.6 \%), p=0.012$ & $41(66.1 \%), p=0.339$ & $97(67.4 \%), p=0.123$ & 0.030 \\
\hline Pneumologists & 97 (33.1\%) & $38(43.7 \%), p=0.064$ & $27(43.5 \%), p=0.094$ & $32(22.2 \%), p<0.001$ & 0.001 \\
\hline Gastroenterologists & $52(17.7 \%)$ & 10 (II.5\%), $p=0.35 \mathrm{I}$ & $6(9.7 \%), p=0.175$ & $36(25.0 \%), p=0.002$ & 0.006 \\
\hline
\end{tabular}

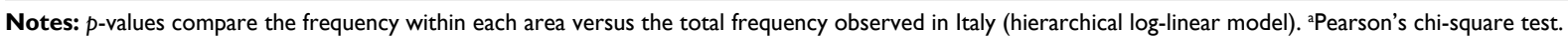


Table 2 Main causes of acute cough within each Italian area as reported by respondents (overall $p=0.013$ among the three Italian areas; Pearson's chi-square test)

\begin{tabular}{|c|c|c|c|c|}
\hline \multirow[t]{2}{*}{ Main causes of cough } & \multirow[t]{2}{*}{ Overall Italy $(n=300)$} & \multicolumn{3}{|l|}{ Italian areas } \\
\hline & & Northern $(n=90)$ & Central $(n=66)$ & Southern $(n=144)$ \\
\hline Viral infections & I 34 (44.7\%) & 40 (44.4\%), $p=0.897$ & $22(33.3 \%), p=0.016$ & $72(50.0 \%), p=0.012$ \\
\hline URTIs & 92 (30.7\%) & $19(21.1 \%), p=0.048$ & $24(36.4 \%), p=0.944$ & $49(34.0 \%), p=0.034$ \\
\hline LRTIs & $22(7.3 \%)$ & $8(8.9 \%), p=0.672$ & $6(9.1 \%), p=0.976$ & $8(5.6 \%), p=0.695$ \\
\hline Allergic rhinitis/asthma & $44(14.7 \%)$ & $21(23.3 \%), p=0.039$ & $10(15.2 \%), p=0.492$ & $13(9.0 \%), p=0.221$ \\
\hline Others & $8(2.7 \%)$ & $2(2.2 \%), p=0.664$ & $4(6.1 \%), p=0.116$ & $2(1.4 \%), p=0.314$ \\
\hline
\end{tabular}

Note: $p$-values compare the frequency within each area versus the total frequency observed in Italy (hierarchical log-linear model).

Abbreviations: LRTIs, lower respiratory tract infections; URTIs, upper respiratory tract infections.

more frequent in Northern regions $(21 / 90,23.3 \%, p=0.039)$. Causes of acute cough among the Italian areas proved significant (overall Pearson's chi-square test $p<0.013$ ).

Regarding chronic cough (Table 3 ), asthma and allergic rhinitis were supposed to be present in the majority of children $(n=160,53.3 \%)$, followed by URTIs $(n=62,20.7 \%)$. Viral $(n=12,4.0 \%)$ and bacterial infections $(n=9,3.0 \%)$ were only episodically indicated as the main cause of chronic cough. LRTIs $(n=33,11.0 \%)$ and gastroesophageal reflux $(n=16,5.3 \%)$ were not regarded as frequent causes of chronic cough in children. We did not find any significant difference in causes of chronic cough among the Italian areas (overall Pearson's chi-square test=not significant [ns]) apart from a significantly higher frequency of viral infections in Central Italy $(\mathrm{n}=8 / 66,12.1 \% ; p=0.002)$.

\section{Therapy}

\section{Acute cough}

Aerosol therapy (such as bronchodilators and/or steroids, in the vast majority of cases) proved as the most preferred route for drug administration ( $n=79,26.3 \%$ of respondents). Oral corticosteroids were prescribed by 30 pediatricians $(10.0 \%)$, and only 24 pediatricians $(8.0 \%)$ gave no treatment for acute cough (Table 4). Significant differences in the treatment were found among the Italian areas $(p<0.001)$. The practice of not treating patients was significantly lower in Northern regions $(2 / 90,2.2 \% ; p=0.016)$ and significantly higher in Central regions $(10 / 66,15.2 \% ; p=0.004)$. The use of aerosol therapy and oral corticosteroids did not show any significant difference across the Italian areas, while symptomatic treatments (antitussive and mucoactive drugs) were more frequent in Southern regions $(33 / 144,22.9 \% ; p=0.048)$. Antibiotics were less prescribed in Southern regions (20/144, 13.9\%; $p=0.001)$, but more recommended in Central regions $(25 / 66$, $37.9 \% ; p=0.005)$, while the use of homeopathic and herbal remedies was higher in Northern regions (22/90, 24.4\%; $p=0.017)$, but lower in Southern regions $(16 / 144,11.1 \%$; $p=0.029$ ).

Significant differences in cough treatment were found according to the presumed causes of acute cough $(p<0.001)$. In allergic rhinitis/asthma $(n=44)$, aerosol therapy $(n=18$, $40.9 \% ; p=0.005)$ and antibiotics $(\mathrm{n}=18,40.9 \% ; p=0.006)$ were the most prescribed drugs. In viral infections $(n=134)$, symptomatics $(\mathrm{n}=33,24.6 \% ; p=0.012)$ and no treatment at all $(\mathrm{n}=20,14.9 \% ; p=0.046)$ were most recommended, while oral corticosteroids were less recommended $(n=10$, $7.5 \% ; p=0.007)$. On the other hand, the most prescribed drugs in URTIs and LRTIs were symptomatics (20/92,

Table 3 Main causes of chronic cough within each Italian area reported by respondents (overall Pearson's chi-square test=ns).

\begin{tabular}{|c|c|c|c|c|}
\hline \multirow[t]{2}{*}{ Main causes of cough } & \multirow[t]{2}{*}{ Overall Italy $(n=300)$} & \multicolumn{3}{|l|}{ Italian areas } \\
\hline & & Northern $(n=90)$ & Central $(n=66)$ & Southern $(n=144)$ \\
\hline Viral infections & $12(4.0 \%)$ & $2(2.2 \%), p=0.384$ & $8(12.1 \%), p=0.002$ & $2(1.4 \%), p=0.076$ \\
\hline URTIs & $62(20.7 \%)$ & $20(22.2 \%), p=0.876$ & $14(2 \mid .2 \%), p=0.979$ & $28(19.4 \%), p=0.893$ \\
\hline LRTIs & $33(11.0 \%)$ & $9(10.0 \%), p=0.554$ & $12(18.2 \%), p=0.119$ & $12(8.3 \%), p=0.268$ \\
\hline Bacterial infections & $9(3.0 \%)$ & $2(2.2 \%), p=0.795$ & I (I.5\%), $p=0.546$ & $6(4.2 \%), p=0.255$ \\
\hline Allergic rhinitis/asthma & $160(53.3 \%)$ & $49(54.4 \%), p=0.80 \mathrm{I}$ & $27(40.9 \%), p=0.284$ & $84(58.3 \%), p=0.255$ \\
\hline Gastroesophageal reflux & $16(5.3 \%)$ & $4(4.4 \%), p=0.595$ & $4(6.1 \%), p=0.737$ & $8(5.6 \%), p=0.839$ \\
\hline Others & $8(2.7 \%)$ & $4(4.4 \%), p=0.143$ & $0, p=0.178$ & $4(2.8 \%), p=0.473$ \\
\hline
\end{tabular}

Note: $p$-values compare the frequency within each area versus the total frequency observed in Italy (hierarchical log-linear model).

Abbreviations: LRTIs, lower respiratory tract infections; ns, not significant; URTIs, upper respiratory tract infections. 
Table 4 First-line treatment indicated by pediatricians for acute cough, stratified according to the different Italian areas, and the causes of acute cough

\begin{tabular}{|c|c|c|c|c|c|c|c|c|c|}
\hline \multirow{2}{*}{$\begin{array}{l}\text { First line } \\
\text { treatments }\end{array}$} & \multirow{2}{*}{$\begin{array}{l}\text { Overall Italy } \\
(n=300)\end{array}$} & \multicolumn{3}{|c|}{ Italian areas } & \multicolumn{5}{|c|}{ Causes of acute cough } \\
\hline & & $\begin{array}{l}\text { Northern } \\
(n=90)\end{array}$ & $\begin{array}{l}\text { Central } \\
(n=66)\end{array}$ & $\begin{array}{l}\text { Southern } \\
(n=144)\end{array}$ & $\begin{array}{l}\text { Allergic rhinitis/ } \\
\text { asthma }(n=44)\end{array}$ & $\begin{array}{l}\text { Viral } \\
\text { infections } \\
(n=134)\end{array}$ & $\begin{array}{l}\text { URTIs } \\
(n=92)\end{array}$ & $\begin{array}{l}\text { LRTIs } \\
(n=22)\end{array}$ & $\begin{array}{l}\text { Others } \\
(n=8)\end{array}$ \\
\hline None & $24(8.0 \%)$ & $\begin{array}{l}2(2.2 \%), \\
p=0.016\end{array}$ & $\begin{array}{l}10(15.2 \%) \\
p=0.004\end{array}$ & $\begin{array}{l}12(8.3 \%) \\
p=0.616\end{array}$ & $0, p=0$ & $\begin{array}{l}20(14.9 \%), \\
p=0.046\end{array}$ & $\begin{array}{l}2(2.2 \%), \\
p=0.194\end{array}$ & $0, p=0.517$ & $\begin{array}{l}2(25.0 \%), \\
p=0.015\end{array}$ \\
\hline Aerosol therapy & 79 (26.3\%) & $\begin{array}{l}21 \text { ( } 23.3 \%), \\
p=0.904\end{array}$ & $\begin{array}{l}12(18.2 \%) \\
p=0.211\end{array}$ & $\begin{array}{l}46(31.9 \%), \\
p=0.134\end{array}$ & 18 (40.9\%), $p=0.005$ & $\begin{array}{l}27(20.1 \%), \\
p=0.388\end{array}$ & $\begin{array}{l}30(32.6 \%), \\
p=0.262\end{array}$ & $\begin{array}{l}4 \text { (I8.2\%), } \\
p=0.78 \mid\end{array}$ & $0, p=0.155$ \\
\hline $\begin{array}{l}\text { Oral } \\
\text { corticosteroids }\end{array}$ & $30(10.0 \%)$ & $\begin{array}{l}10 \text { (1I.1\%), } \\
p=0.250\end{array}$ & $\begin{array}{l}3(4.5 \%) \\
p=0.102\end{array}$ & $\begin{array}{l}17 \text { (11 } 1.8 \%) \\
p=0.292\end{array}$ & $6(13.6 \%), p=0.201$ & $\begin{array}{l}10(7.5 \%) \\
p=0.007\end{array}$ & $\begin{array}{l}10(10.9 \%), \\
p=0.36 \mid\end{array}$ & $\begin{array}{l}2(9.1 \%) \\
p=0.945\end{array}$ & $\begin{array}{l}2(25.0 \%), \\
p=0.296\end{array}$ \\
\hline Symptomatics & $53(17.7 \%)$ & $\begin{array}{l}14(15.6 \%) \\
p=0.686\end{array}$ & $\begin{array}{l}6(9.1 \%) \\
p=0.079\end{array}$ & $\begin{array}{l}33(22.9 \%), \\
p=0.048\end{array}$ & $0, p=0.237$ & $\begin{array}{l}33(24.6 \%), \\
p=0.012\end{array}$ & $\begin{array}{l}20(21.7 \%), \\
p=0.011\end{array}$ & $0, p=0.407$ & $0, p=0.833$ \\
\hline Antibiotics & $66(22.0 \%)$ & $\begin{array}{l}21 \text { (23.3\%), } \\
p=0.749\end{array}$ & $\begin{array}{l}25 \text { (37.9\%), } \\
p=0.005\end{array}$ & $\begin{array}{l}20(13.9 \%), \\
p=0.00 I\end{array}$ & 18 (40.9\%), $p=0.006$ & $\begin{array}{l}20(14.9 \%), \\
p=0.066\end{array}$ & $\begin{array}{l}16(17.4 \%), \\
p=0.427\end{array}$ & $\begin{array}{l}12(54.5 \%) \\
p=0.010\end{array}$ & $0, p=0.148$ \\
\hline Phytotherapics & $48(16.0 \%)$ & $\begin{array}{l}22(24.4 \%), \\
p=0.017\end{array}$ & $\begin{array}{l}10 \text { (15.2\%), } \\
p=0.857\end{array}$ & $\begin{array}{l}16(11.1 \%) \\
p=0.029\end{array}$ & $2(4.5 \%), p=0.203$ & $\begin{array}{l}24 \text { (17.9\%), } \\
p=0.316\end{array}$ & $\begin{array}{l}14(15.2 \%), \\
p=0.40 \mid\end{array}$ & $\begin{array}{l}4(18.2 \%), \\
p=0.558\end{array}$ & $\begin{array}{l}4(50.0 \%), \\
p=0.070\end{array}$ \\
\hline Overall $p$-value $\mathrm{e}^{\mathrm{a}}$ & - & $p<0.001$ & & & $p<0.001$ & & & & \\
\hline
\end{tabular}

Notes: $p$-values compare the frequency within each area versus the total frequency observed in Italy (hierarchical log-linear model). aPearson's chi-square test. Abbreviations: LRTIs, lower respiratory tract infections; URTIs, upper respiratory tract infections.

$21.7 \% ; p=0.011)$ and antibiotics $(12 / 22,54.5 \% ; p=0.010)$, respectively.

\section{Chronic cough}

Aerosol therapy and antibiotics were the most used medications also in chronic cough (Table 5). Aerosol therapy was widely used across the Italian areas, without any significant difference from each other. Aerosol was frequently prescribed when allergic rhinitis and asthma were presumed (98/160, $61.3 \% ; p<0.001)$. Systemic corticosteroids were rarely used, and their prescription did not show any significant geographical difference and etiological distribution. The use of symptomatics (antitussives and mucolytics) proved homogeneously distributed across Italian areas, for all causes of cough. The prescription of antibiotics proved scattered across the different regions, and antibiotics were more frequently prescribed when URTIs $(42 / 62,67.7 \% ; p=0.036)$ and LRTIs $(24 / 33,72.7 \% ; p=0.024)$ were presumed. As in the case of acute cough, the use of homeopathic and herbal remedies in chronic cough was significantly higher in Northern regions $(8 / 90,8.9 \%, p=0.010)$, independent of the causes. Finally, gastroprotectants (such as antacids and/or proton pump inhibitors) were equally used among Italian areas, particularly when the presence of gastroesophageal reflux was strongly presumed $(10 / 16,62.5 \% ; p<0.001)$.

Both in acute and in chronic cough, the most prescribed classes of antibiotics were penicillins (amoxicillin; amoxicillin/clavulanate) in 54\%, macrolides (clarithromycin; azithromycin) in $25 \%$, and cephalosporins in $19 \%$ of cases.

\section{Discussion}

The present survey provided interesting data, both in terms of the number of pediatricians surveyed $(n=300)$ and of the geographical representativeness of the sample (15 Italian regions, covering $\sim 300,000$ children).

Interesting insights and numerous confirmations emerged concerning the attitudes of pediatricians toward diagnosis and treatment of cough.

First, cough prevalence was reported without any clear seasonality. Although cough has been generally regarded as a "winter illness" due to low temperatures, present data tend to confirm the evidence from the literature that suggests that cough has an impact on the pediatricians' activity throughout the year, due to allergy, smog, and gastric reflux. ${ }^{18-20}$ Actually, even if $>99 \%$ of the pediatricians surveyed regard cough as a winter trouble, $65 \%$ of them affirmed that cough is also highly prevailing in spring and summer. In addition, pediatricians also described acute cough as more frequently dry, while chronic cough as more frequently productive.

Pediatricians often tended to link cough to self-limiting infectious causes. This attitude is in accordance with international guidelines ${ }^{21-23}$ since only $14 \%$ of pediatricians believe that an active intervention in this sense is needed.

The attitude proved different in order to clarify the etiology of chronic cough, and approximately three-fourth of respondents claimed to ask for some investigations. Nevertheless, the diagnostic approach revealed some weaknesses and inconsistencies. A very high demand for allergological investigations was documented (84\%), with a substantial 


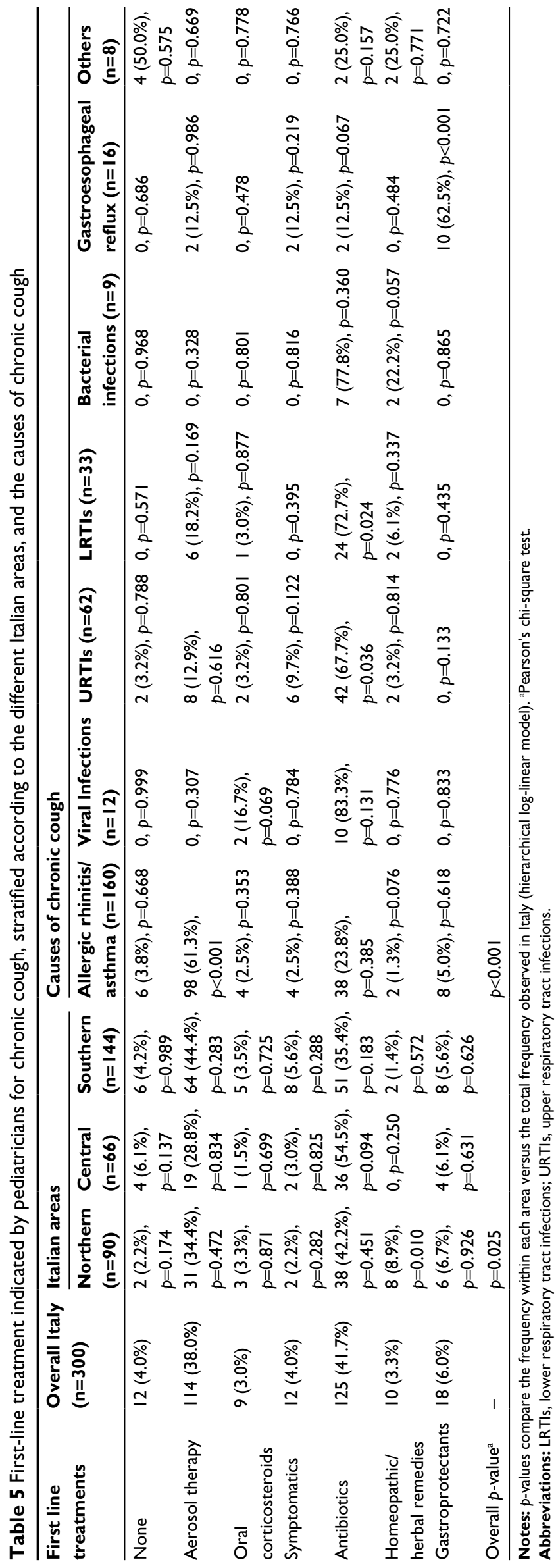

discrepancy between the suspicion of allergies and the request for pulmonary function tests (33\%); this is in contrast with the international guidelines that do suggest spirometry in children aged $>5$ years in these cases. ${ }^{21,22,24}$

Pediatricians indicated URTI and viral infections as the main causes of acute cough ( $31 \%$ and $45 \%$, respectively), and their belief is in agreement with the current literature. ${ }^{25}$ The analysis within the different geographical areas showed some differences in allergic diseases and asthma, which are presumed to be more prevalent in Northern regions in the present survey. This evidence is in contrast with a previous survey that was carried out by focusing families and children. ${ }^{26}$

The most suspected causes of chronic cough were asthma, postnasal drip syndrome, and bronchitis, as reported in the literatures. ${ }^{21,22,24,27,28} \mathrm{~A}$ recent review by Chang et $\mathrm{al}^{28}$ suggested an overestimation of asthma as the primary cause of chronic cough in children, compared to bronchitis. This aspect is unavoidably mirrored by the therapeutic management of cough. Allergic disease was the most frequently suggested cause of chronic cough in children (53\%), and this proved supported by the high demand for consultations: $73 \%$ seek the opinion of allergologists, $62 \%$ of otolaryngologists, and only $33 \%$ of pulmonologists.

Data from the present survey have some arguable aspects. While in acute, uncomplicated cough due to upper airway infections, the guidelines suggest to refrain from any treatment, ${ }^{21,22}$ in the present survey, only $8 \%$ of pediatricians prescribed no medications for acute cough, followed by symptomatic treatments prescribed very often.

Even if antibiotics are recommended if a loose cough persists for $>4$ weeks after an URTI because it might suggest the occurrence of bacterial bronchitis, antibiotic treatment in acute pediatric cough still proves overused. Although the recognized lack of efficacy for this therapeutic strategy, neither in common cold nor in viral infections, ${ }^{29-31}$ the rates of prescription proved very high in the present survey. There was an excessive use of antibiotics in acute cough, particularly in allergic rhinitis/asthma (41\%) and URTIs (17\%). Moreover, despite the recent evidence that symptomatic treatments, such as either mucoactive or antitussive drugs, according to the type of cough, are more effective than antibiotics in acute cough, ${ }^{32,33}$ the antibiotic prescription still confirms widespread and likely led by patient/parent suggestions, as already verified in the primary care setting. ${ }^{34}$

Aerosol therapy confirms as the most prescribed treatment for cough, but the nebulized drugs used are frequently corticosteroids and bronchodilators, both in acute and chronic cough, regardless of the cough etiology. However, it should be noted that the aerosol therapy and the bronchodilator use 
in particular do not improve the recovery from cough due to URTIs in non-asthmatic children. ${ }^{35,36}$

We would finally highlight that the use of mucoactive and antitussive drugs was scarce compared to homeopathic and herbal remedies. These remedies are likely regarded as "safer" for children, ${ }^{31,37}$ even if recent data have suggested that mucoactives and antitussives may have a role in reducing acute cough in children as an alternative to antibiotics prescription, which is largely ineffective when cough is due to viral infections. ${ }^{32,33}$

The present survey has some limitations. First, the question about the causes of cough can lead to some misinterpretations, because respondents mainly indicated a general etiology for cough rather than a specific disease. For instance, several pediatricians reported allergy as a general cause of cough, while a more detailed definition of the allergy-related diseases, such as asthma, rhinitis, and eosinophilic bronchitis, would have allowed a more precise cough etiology. ${ }^{31-41}$

Moreover, open questions about the causes of cough introduced some problems in discriminating a wide range of acute URTIs, such as sinusitis, pharyngitis, laryngitis, tracheitis, and bronchitis. In order to indicate URTIs of possible viral etiology, URTIs with unspecified etiology and viral infections were included in "URTI", just pooling this large variety of conditions.

\section{Conclusion}

Data of the present survey tend to confirm that cough is a very common and multifaceted problem in children and that it is prevailing throughout all the year. The great majority of pediatricians tend to prescribe drugs in acute cough regardless of cough guidelines. In the management of chronic cough, they search for a possible etiology, but frequently they are not perfectly oriented. On the other hand, the extremely high requests for allergologic tests do not match with the clinical suspicion for asthma. Regarding cough's treatment, there is a strong need of promoting much more rational strategies for antimicrobial use. Actually, both the incomplete diagnostic procedures and the incorrect therapeutic approach (particularly the antibiotic misuse) can substantially affect the burden of cough.

\section{Disclosure}

The authors report no conflicts of interest in this work.

\section{References}

1. Chang AB, Robertson CF, Van Asperen PP, et al. A multicenter study on chronic cough in children : burden and etiologies based on a standardized management pathway. Chest. 2012;142:943-950.
2. Smith MD, Spiller HA, Casavant MJ, Chounthirath T, Brophy TJ, Xiang H. Out-of-hospital medication errors among young children in the United States, 2002-2012. Pediatrics. 2014;134(5):867-876.

3. Chang AB, Robertson CF, van Asperen PP, et al. A cough algorithm for chronic cough in children: a multicenter, randomized controlled study. Pediatrics. 2013;131(5):e1576-e1583.

4. Risk R, Naismith H, Burnett A, Moore SE, Cham M, Unger S. Rational prescribing in paediatrics in a resource-limited setting. Arch Dis Child. 2013;98:503-509.

5. Picciotto A, Hubbard M, Sturdy P, Naish J, McKenzie SA. Prescribing for persistent cough in children. Respir Med. 1998;92(4):638-641.

6. Chai G, Governale L, McMahon AW, Trinidad JP, Staffa J, Murphy D. Trends of outpatient prescription drug utilization in US children, 2002-2010. Pediatrics. 2012;130:23-31.

7. Gulliford MC, Dregan A, Moore MV, et al. Continued high rates of antibiotic prescribing to adults with respiratory tract infection: survey of 568 UK general practices. BMJ Open. 2014;4(10):e006245.

8. Hersh AL, Shapiro DJ, Pavia AT, Shah SS. Antibiotic prescribing in ambulatory pediatrics in the United States. Pediatrics. 2011;128(6):1053-1061.

9. Schindler C, Krappweis J, Morgenstern I, Kirch W. Prescriptions of systemic antibiotics for children in Germany aged between 0 and 6 years. Pharmacoepidemiol Drug Saf. 2003;12(2):113-120.

10. Costelloe C, Metcalfe C, Lovering A, Mant D, Hay AD. Effect of antibiotic prescribing in primary care on antimicrobial resistance in individual patients: systematic review and meta-analysis. BMJ. 2010;340:c2096-c2096.

11. Goossens H. Antibiotic consumption and link to resistance. Clin Microbiol Infect. 2009;15(suppl 3):12-15.

12. Oppong R, Coast J, Hood K, Nuttall J, Smith RD, Butler CC; GRACE01 Study Team. Resource use and costs of treating acute cough/lower respiratory tract infections in 13 European countries: results and challenges. Eur J Health Econ. 2011;12(4):319-329.

13. Hollinghurst S, Gorst C, Fahey T, Hay AD. Measuring the financial burden of acute cough in pre-school children: a cost of illness study. BMC Fam Pract. 2008;9:10.

14. McCallum GB, Bailey EJ, Morris PS, Chang AB. Clinical pathways for chronic cough in children. Cochrane Database Syst Rev. 2014;9:CD006595.

15. Chang AB, Oppenheimer JJ, Weinberger M, Weir K, Rubin BK, Irwin RS. Use of management pathways or algorithms in children with chronic cough: systematic reviews. Chest. 2016;149(1):106-119.

16. Rousounidis A, Papaevangelou V, Hadjipanayis A, et al. Descriptive study on parents' knowledge, attitudes and practices on antibiotic use and misuse in children with upper respiratory tract infections in Cyprus. Int J Environ Res Public Health. 2011;8:3246-3262.

17. Vinson DC, Lutz LJ. The effect of parental expectations on treatment of children with a cough: a report from ASPN. J Fam Pract. 1993;37(1): 23-27.

18. Morice AH. Epidemiology of cough. Pulm Pharmacol Ther. 2002; 15(3):253-259.

19. Kauffmann F, Varraso R. The epidemiology of cough. Pulm Pharmacol Ther. 2011;24(3):289-294.

20. Dicpinigaitis PV, Eccles R, Blaiss MS, Wingertzahn MA. Impact of cough and common cold on productivity, absenteeism, and daily life in the United States: ACHOO Survey. Curr Med Res Opin. 2015;31(8):1519-1525.

21. Chang AB, Glomb WB. Guidelines for evaluating chronic cough in pediatrics: ACCP evidence-based clinical practice guidelines. Chest. 2006;129(1 suppl):260S-283S.

22. Shields MD, Bush A, Everard ML, McKenzie S, Primhak R, British Thoracic Society Cough Guideline Group. BTS guidelines: recommendations for the assessment and management of cough in children. Thorax. 2008;63:iii1-iii15.

23. Gibson PG, Chang AB, Glasgow NJ, et al. CICADA: cough in children and adults: diagnosis and assessment. Australian cough guidelines summary statement. Med J Aust. 2010;192(5):265-271.

24. Morice AH. The diagnosis and management of chronic cough. Eur Respir J. 2004;24:481-492.

25. Worrall G. Acute cough in children. Can Fam Physician. 2011;57: 315-318. 
26. [No authors listed]. Asthma and respiratory symptoms in 6-7 yr old Italian children: gender, latitude, urbanization and socioeconomic factors. SIDRIA (Italian Studies on Respiratory Disorders in Childhood and the Environment). Eur Respir J. 1997;10(8):1780-1786.

27. Usta Guc B, Asilsoy S, Durmaz C. The assessment and management of chronic cough in children according to the British Thoracic Society guidelines: descriptive, prospective, clinical trial. Clin Respir J. 2014;8(3):330-337.

28. Chang AB, Oppenheimer JJ, Weinberger M, Rubin BK, Irwin RS. Children with chronic wet or productive cough-treatment and investigations: a systematic review. Chest. 2016;149:120-142.

29. Smith SM, Fahey T, Smucny J, Becker LA. Antibiotics for acute bronchitis. Cochrane Database Syst Rev. 2014;3:CD000245.

30. Kenealy T, Arroll B. Antibiotics for the common cold and acute purulent rhinitis. Cochrane Database Syst Rev. 2013;6:CD000247.

31. Zanasi A, Cazzato S, Mazzolini M, et al. Does additional antimicrobial treatment have a better effect on URTI cough resolution than homeopathic symptomatic therapy alone? A real-life preliminary observational study in a pediatric population. Multidiscip Respir Med. 2015;10(1):25.

32. Zanasi A, Lanata L, Fontana G, Saibene F, Dicpinigaitis P, De Blasio F. Levodropropizine for treating cough in adult and children: a metaanalysis of published studies. Multidiscip Respir Med. 2015;10(1):19.

33. Zanasi A, Cazzato S, Aprile A, Mazzolini M, Zenezini C, Pandolfi P. Are antibiotics effective in treating children with acute moist cough? A retrospective study vs symptomatic therapy. Multidiscip Respir Med. 2012; 7:I-V.
34. Ashworth M, White P, Jongsma H, Schofield P, Armstrong D. Antibiotic prescribing and patient satisfaction in primary care in England: crosssectional analysis of national patient survey data and prescribing data. Br J Gen Pract. 2016;66(642):e40-e46.

35. Bernard DW, Goepp JG, Duggan AK, Serwint JR, Rowe PC. Is oral albuterol effective for acute cough in non-asthmatic children? Acta Paediatr. 1999;88(4):465-467.

36. Smucry JJ, Flynn CA, Becker LA, Glazier RH. Are b2 agonists effective treatment for acute bronchitis or acute cough in patients without underlying pulmonary disease? A systematic review. J Fam Pract. 2001; 50:945-951.

37. Hampton LM, Nguyen DB, Edwards JR, Budnitz DS. Cough and cold medication adverse events after market withdrawal and labeling revision. Pediatrics. 2013;132(6):1047-1054.

38. Brightling CE. Chronic cough due to nonasthmatic eosinophilic bronchitis: ACCP evidence-based clinical practice guidelines. Chest. 2006;129(1 suppl):116S-121S.

39. Dicpinigaitis PV. Chronic cough due to asthma: ACCP evidence-based clinical practice guidelines. Chest. 2006;129(1 suppl):75S-79S.

40. Pratter MR. Chronic upper airway cough syndrome secondary to rhinosinus diseases (previously referred to as postnasal drip syndrome): ACCP evidence-based clinical practice guidelines. Chest. 2006;129(1 Suppl): 63S-71S.

41. Pecova R, Zucha J, Pec M, Neuschlova M, Hanzel P, Tatar M. Cough reflex sensitivity testing in in seasonal allergic rhinitis patients and healthy volunteers. J Physiol Pharmacol. 2008;59(suppl 6):557-564. 


\section{Supplementary material}

\section{Questionnaire for investigating the pediatricians' approach to cough}

Cough is a symptom which is common to several diseases, and which represents the most frequent reason for a pediatric consultation, due to the anxiety and discomfort induced.

Some clinical investigations are needed in order to precise the origin of cough, particularly when it is persisting for long periods, and causes significant limitations in patient's daily-life activities.

The present questionnaire is aimed to investigate anonymously the diagnostic and therapeutic behavior of pediatricians in the presence of cough.

Thank you for your valuable cooperation.

1) In which Region are you working?

2) For how many years?

3) How many patients have you in charge

4) How prevalent is cough in your practice over the period October-March?

$\square$ very rare $\square$ occasional $\quad \square$ frequent $\quad \square$ very frequent

5) $\quad \ldots$ and over the period April-September?

$\square$ very rare $\square$ occasional $\square$ frequent $\square$ very frequent

6) Over a 12-month period, was the same patient referred to you for cough:

$\square$ very rarely $\square$ occasionally $\square$ frequently $\square$ very frequently

7) In your experience, acute cough is mostly:

$\square$ dry $\quad \square$ with secretions

8) In your experience, chronic cough ( $>4$ week duration) is mostly:

$\square$ dry $\quad \square$ with secretions

9) Cough should be carefully and deeply investigated:

In Acute cough $\quad \square$ Never $\quad \square$ Rarely $\quad \square$ Frequently $\quad \square$ Always

( $\leq 4$ week duration)

In Chronic cough $\quad \square$ Never $\quad \square$ Rarely $\quad \square$ Frequently $\quad \square$ Always

(>4 week duration)

10) Which ones of these investigations are you mostly requiring in the presence of acute cough ( $\leq 4$ week duration)? (Maximum 3 answers) (Skip this question if you answered NEVER to the question \# 9)

$\square$ Chest X Ray

$\square$ Spirometry

$\square$ Allergic tests

$\square$ Other (please, specify)

11) Which ones of these investigations are you mostly requiring in the presence of chronic cough ( $>4$ week duration)? (Maximum 3 answers) (Skip this question if you answered NEVER to the question \# 9)

$\square$ Chest X Ray

$\square$ Spirometry

$\square$ Allergic tests

$\square$ Sweat test

$\square$ Gastro-esophageal pH-metry

$\square$ CT Scan of paranasal sinuses

$\square$ Other (please, specify) 
12) To which specialist do you mostly refer in the presence of chronic cough? (Maximum 3 answers)

$\square$ Otorhinolaryngologist

$\square$ Pneumologist

$\square$ Allergologist

$\square$ Gastroenterologist

$\square$ None

$\square$ Other (please, specify)

13) Which are the most frequent causes of acute cough ( $\leq 4$ week duration) in your activity?

1 .......................................

2

14) When facing the most frequent cause of acute cough (the 1st one claimed in question \# 13), which drugs do you usually prescribe as first-line options? (Maximum 3 answers)

$\square$ Steroid and bronchodilators via aerosol

$\square$ Oral steroids

$\square$ Mucoactives

$\square$ Cough suppressants

$\square$ Antibiotics

$\square$ Homeopathic drugs

$\square$ Herbal remedies

$\square$ Other (please, specify)

15) When facing the 2nd most frequent cause of acute cough (the 2nd one claimed in question \# 13), which drugs do you usually prescribe as first-line options? (Maximum 3 answers)

$\square$ Steroid and bronchodilators via aerosol

$\square$ Oral steroids

$\square$ Mucoactives

$\square$ Cough suppressants

$\square$ Antibiotics

$\square$ Homeopathic drugs

$\square$ Herbal remedies

$\square$ Other (please, specify)

16) Which are the most frequent causes of chronic cough ( $>4$ week duration) in your activity?

1 ......

2 .

17) When facing the most frequent cause of chronic cough (the 1st one claimed in question \# 16), which drugs do you usually prescribe as first-line options? (Maximum 3 answers)

$\square$ Steroid and bronchodilators via aerosol

$\square$ Oral steroids

$\square$ Mucoactives

$\square$ Cough suppressants

$\square$ Antibiotics

$\square$ Homeopathic drugs

$\square$ Herbal remedies

$\square$ Other (please, specify)

18) When facing the 2nd most frequent cause of chronic cough (the 2nd one claimed in question \# 16), which drugs do you usually prescribe as first-line options? (Maximum 3 answers)

$\square$ Steroid and bronchodilators via aerosol

$\square$ Oral steroids 


\section{$\square$ Mucoactives \\ $\square$ Cough suppressants \\ $\square$ Antibiotics \\ $\square$ Homeopathic drugs \\ $\square$ Herbal remedies \\ $\square$ Other (please, specify)}

Note: This is an English translation of the original version of this questionnaire, which was presented in Italian.

ClinicoEconomics and Outcomes Research is an international, peerreviewed open-access journal focusing on health technology assessment, pharmacoeconomics and outcomes research in the areas of diagnosis, medical devices, and clinical, surgical and pharmacological intervention. The economic impact of health policy and health systems organization also constitute important areas of coverage. The manuscript management system is completely online and includes a very quick and fair peer-review system, which is all easy to use. Visit http://www.dovepress.com/testimonials.php to read real quotes from published authors.

Submit your manuscript here: https://www.dovepress.com/clinicoeconomics-and-outcomes-research-journal 